\title{
Intercultural Awareness Through English Language Teaching: The Case of Kosovo
}

\author{
Leonora Gashi ${ }^{1}$ D
}

Received: 2 April 2019 / Accepted: 29 June 2021 / Published online: 13 July 2021

(c) The Author(s) 2021

\begin{abstract}
This study seeks to understand opportunities for teaching and learning the target culture for intercultural awareness. Utilizing Moran's Knowing Framework (2001) and its five cultural dimensions, and reviewing curriculum documents and the English textbook in use for Grade Six in Kosovo, the study finds a misalignment among curriculum documents and the textbook regarding teaching culture for cultural understanding. It is noted that while curriculum documents share the goals and objectives for preparing students to become global citizens through language and culture learning in the English language, this vision is lost along the way and rarely makes it to the English language classrooms. It is concluded that English teachers, in Kosovo and potentially internationally, need to be more creative in utilizing more authentic cultural materials in their classes to bring to life the target culture. Lastly, it is argued that learning about another culture and comparing it with one's own helps students examine their culture from a different perspective, which in turn potentially makes culturally-richer individuals in deeper and closer touch with their culture as well as cultures around them, near and far.
\end{abstract}

Keywords Teaching culture - Intercultural awareness $\cdot$ EFL curriculum $\cdot$ L1 and L2 culture $\cdot$ Kosovo

\section{Introduction}

Teaching English to speakers of other languages is a global phenomenon. As a result, there is a growing interest in the field of English language teaching to find effective ways to help teachers maximize student learning. Another less studied component of English language teaching is teaching the culture or elements of it that accompany the English language teaching, and it has only recently attracted some

\section{Leonora Gashi}

leonora.gashi@ntnu.no

1 Department of Teacher Education, Norwegian University of Science and Technology (NTNU), 7491 Trondheim, Norway 
attention in Europe (Lipovec, 2017; Vettorel \& Lopriore, 2013). Subsequently, this article focuses on the question "How is the target culture taught in Grade Six in the Kosovo context?" The underlying assumption of the importance of teaching the target culture is that it increases intercultural awareness. Intercultural awareness is defined as part of intercultural communication competence, which as such is defined as "the ability to effectively and appropriately execute communication behaviors that negotiate each other's cultural identity or identities in a culturally diverse environment (Chen \& Starosta, 1998, p. 28). Further, Chen and Starosta (1998) define intercultural awareness as "the cognitive aspect of intercultural communication competence that refers to the understanding of cultural conventions that affect how we think and behave" (p. 28). The core idea behind the intercultural awareness is that it increases citizens' intercultural understanding in the interconnected globalized world as a result of the advancement of technological developments that have made the world a smaller place.

Specifically, this study pertains to teaching the target culture while teaching English as a foreign or second language by teachers who also speak English as a foreign language. The terms intercultural understanding and cultural awareness are used interchangeably as established by literature (Garrido \& Álvarez, 2006). Cultural awareness, for example, means becoming aware of cultural values, beliefs or perceptions, be those ours or others' cultures. Culture itself is the broader term that incudes these two and more that relates to how people live within a bounded space. In addition, the study uses English as a Second Language (ESL) and English as a Foreign Language (EFL) interchangeably; understanding that there are underlying differences between the two constructs in the way they are used around the world. For example, English is referred to as EFL in the Kosovo context, but the United States (U.S.) uses ESL to refer to students whose native language is not English.

Relying on analysis of key documents, the study aimed to examine the national curriculum, the grade six English curriculum, and the English textbooks in relation to teaching the target culture. Based on the findings, the article recommends alternatives as to how the identified gaps in policy and curriculum documents and instructional materials could be filled. Ways in which English language teachers could help students develop their intercultural awareness of the target culture using English language textbooks and additional teaching and learning resources are also suggested.

The article is organized as follows: first the importance of teaching culture to Kosovo students and a brief context of the study is presented, followed by the theoretical framework and the literature review, and then the methodological considerations. Next, the article presents the findings in light of literature that addresses intercultural awareness and the target culture, primarily through language teaching. Lastly, the article presents conclusions, and offers a set of recommendations on how the Kosovo English textbooks could be revised to better integrate culture for purposes of increasing intercultural awareness into English language teaching practices and methods. 


\section{The Importance of Teaching Culture to Kosovo Students and Context of the Study}

Language and culture are tightly knit together. Teaching one without the other makes the language learning abstract because the language as a means of communication is contextual and embedded into its culture. With English being an international language and considering dominance of American culture around the world, mainly through movies, music and media in general, language learning without this component is limited. Therefore, it is important that Kosovo students benefit from their English language curriculum not only in terms of foreign language acquisition but also in terms of the culture in which it is mostly embedded. Also, while British English used to be taught in Kosovo, more textbooks written in American English are being introduced. This is the case for lower secondary grades where the textbooks follow the United States (U.S.) convention, while those in the high schools follow the United Kingdom (UK) convention. This primarily depends on which textbooks the Kosovo's Ministry of Education decides to use, and then where those textbooks are originally published, i.e. whether publishers originate from the U.S., such as Pearson, or from UK, such as Cambridge University Press.

There are claims that imperialism is another process that has drawn English to be a global language. Imperialism is defined as the transfer of a dominant language (and aspects of its culture) to speakers of other languages and linguistic imperialism assumes the active promotion of the language by the dominant class as the active expression of power of the powerful over the powerless (Phillipson, 1992). However, this is not the case in Kosovo. Based on Kosovo's recent history and its excellent political relations with the United States and Great Britain, learning English in Kosovo is not seen as an imperialist effort, rather due to its relevance for educational and job opportunities, English is viewed as a necessary skill or competence that advances one's career or at least puts available opportunities locally or internationally within reach. In other words, English language mastery is viewed as empowerment of oneself and as a step closer to the Western world.

\section{Context of the Study: Kosovo}

Territory- and population-wise, Kosovo is a small country. It has an area of about $10000 \mathrm{~km}^{2}$ and a population of about 1.8 million as per the latest census of 2012 (ASK, n.d.). The majority of the population is Albanian (about 92\%), while the other $8 \%$ include Serb, Bosnian, Turkish, Roma, Ashkali, Egyptian and Gorani communities. There are two official languages at the national level, Albanian and Serbian. The language of instruction is Albanian, Serbian, Turkish and Bosnian, depending on where these communities live, and it spans from kindergarten to the end of high school. Higher education is available only in Albanian and Serbian in the public institutions, and English in some private institutions-such as the Rochester Institute of Technology in Kosovo. 
Kosovo is a newly established state-it declared independence from Serbia in 2008. After the conflict ended in 1999, Kosovo education system was introduced to major changes for the first time after more than a decade of occupation. The changes required intensive work from international organizations and local experts to create and introduce a new curriculum, new teaching methodologies, new assessment techniques, new textbooks, and new professional development opportunities for teachers (Tahirsylaj, 2013, 2018). However, there is little research that sheds light on the extent to which the intended policy changes have actually found their way into classrooms. One finding was that teachers did not feel they had ownership over the reforms and that they faced numerous challenges during the implementation (Tahirsylaj, 2013).

Educational change in post-war Kosovo was preceded by development of new curriculum frameworks. The first curriculum framework was called The New Kosovo Curriculum Framework (MEST, 2001). This was the first time when many international experts were involved in the creation of it. The framework notes, "[...] the education system has been isolated from ongoing international development and as a result the teaching process was isolated from professional innovations such as learner-centered and interactive methodologies" (MEST, 2001, p. 11). English language teaching was also teacher-centered and far from recent child-centered methods. It was mostly concentrated in reading comprehension or learning words out of context. Students in K-12 schools almost never had a chance to practice the English language with a native speaker or stimulate dialogues and situations where they could use it with each other in the classroom. This situation was further aggravated by the fact that there was little or no technology integration in classrooms. For example, even in cases when textbooks included a CD or tape that contained dialogues read or played by native speakers, they were almost never used since there were no $\mathrm{CD}$ players or radios in the school to be utilized by teachers for language teaching and learning purposes.

English is currently taught from grade 1 in Kosovo, compared to grade 3 before 2010 and grade 5 before the war in 1999. A new curriculum framework was adopted in Kosovo in 2011. This most recent framework called Curriculum Framework for Pre-university Education in the Republic of Kosovo (MEST, 2011) introduced for the first time competence-based education, where English Language is part of Language and Communication learning area. The framework required introduction of English as a foreign language from grade 1. Both frameworks of 2001 and 2011 highlighted the positive role of English language learning for intercultural awareness and emphasized the importance of learning about other nations and cultures for accessing and sharing information internationally and effectively for navigating the interconnected global world.

\section{Theoretical Framework and Literature Review}

Before delving into teaching culture for intercultural awareness, a definition of culture is provided first, even though there are many definitions of it. As Hinkel (1999) states it may not be an exaggeration to say that there are nearly as many definitions 
of culture as there are fields of inquiry into human societies, groups, systems, behaviors, and activities. Here, the article primarily relies on the definition from Patrick Moran (Moran, 2001), who notes that culture includes products, practices, perspectives, communities and persons. In his words,

Products are all artifacts such as clothing, written documents, written or spoken language, family, education, politics, economy and religion [...] Practices include language or other forms of communication or of self expression and actions associated with social groups and use of products. [...] Perspectives represent the perceptions, beliefs, values and attitudes that underlie the products and that guide persons and communities in the practices of the culture. [...] Communities include the specific social contexts, circumstances, and groups in which groups carry out cultural practices [...] Persons constitute the individual members who embody the culture and its communities in unique ways. Each person is a distinct mix of communities and experiences, and all persons take on particular cultural identity that both links them to and separates them from other members of the culture. [...] (Moran, 2001, p. 25, emphasis in the original)

Many loaded concepts are packed into this extended quote and different authors use different concepts to refer to the same ideas. For example Chen and Starosta (1998) use cultural conventions to incorporate all aspects of a specific culture. However, Moran (2001) provides a more comprehensive overview of each key component of the culture, encompassing products, practices, perspectives, communities and persons of any given culture anywhere in the world. Moran's (2001) definition of culture is used as a guiding framework to analyze the Grade Six English language textbook used in Kosovo schools.

So what does teaching culture for intercultural awareness mean then? According to Moran (2001), each cultural dimension relates to the nature of language and culture. Thus, when cultural dimension of products is in question, the language used in classrooms deals with description and manipulation of cultural products, such as literature, arts, architecture, or music, among else. Moran also notes that language is a "cultural product in and of itself," (Moran, 2001, p. 36) which is understandable considering that all unique languages are embedded within unique cultures in which those languages emerged, developed and continue to be modified and transformed.

The other cultural dimension, the one of practices, relates to the language used to participate in cultural practices (Moran, 2001). Indeed, language is the medium that makes possible participation in cultural practices. For example, as Moran notes, participation in a marriage ceremony involves both written and spoken language participation in the form of sending invitations or welcoming guests, and being able to say the right thing at the right time so that no culturally-inappropriate and insensitive remarks are made. Further, the cultural dimension of perspectives deals with the language used to identify, explain, and justify cultural perspectives. In Moran's (2001) words, "Through language, we make tacit perspectives explicit. [...] Words, phrases, idioms, expressions-when we examine what they mean-reveal values, attitudes, and beliefs intrinsic to the culture" (p. 37). One challenge regarding cultural perspectives has to do with the ability of the outsiders to decipher cultural phrases, 
idioms and expressions. Unless an outsider is fully aware of and deeply understands the meaning behind those cultural elements, it is difficult, and in cases impossible, to use them appropriately in an EFL classroom.

The cultural dimension of communities refers to the language used to participate appropriately in specific cultural communities. Moran (2001) highlights that "Communities develop distinct language to describe and carry out the particular practices and products associated with their group and its activities" (p. 38). For example, linguists, politicians and computer technicians all have specialized language that describes the work that they do, which in turn, fits the activities they are engaged in. This is particularly important in ESL settings where students are focusing their language learning for specific study programs abroad.

Lastly, the cultural dimension of persons relates to the language individuals use to express their unique identity within the culture. In this sense, both language and culture are not viewed only as collective but also as personal.

"Each of us has a unique manner of self-expression in the language - a tone of voice, a certain pitch, a way of pronouncing, an accent, a writing voice, a communicative style, a preference for certain words, expressions, and idioms. We use our own version of language to describe, understand and respond to our experiences and ourselves" (Moran, 2001, p. 38)

This cultural dimension is very important when examining language and culture at a micro-level perspective, i.e. within-persons perspective. Based on the above cultural dimensions, Moran (2001, p. 39) developed his Cultural Knowing Framework, to frame the way of using language to learn culture. Table 1 includes elements of Moran's framework.

As Table 1 shows, Moran's framework (2001) is based on the cultural dimensions, and here it adds some complexity in terms of the stages that the development of intercultural awareness goes through, starting from participation, to description, to interpretation, and to response. Each of these stages reflects one aspect of the Knowing framework, namely, knowing how, about, why and knowing oneself. Also, Table 1 highlights the nature of language per each stage, and again, it pertains to the nature of language involved in the five cultural dimensions described above. The framework assumes that teachers are native speakers of the target language and thus

Table 1 Moran's cultural knowing framework (2001) of language use to learn culture

\begin{tabular}{ll}
\hline Stage & The nature of language \\
\hline Participation: knowing how & The language used to participate in the cultural experience \\
Description: knowing about & The language used to describe the cultural experience \\
Interpretation: knowing why & $\begin{array}{l}\text { The language used to identify, explain, and justify cultural } \\
\text { perspectives and to compare and contrast these with } \\
\text { perspectives from the individual's own culture and other } \\
\text { cultures } \\
\text { The language individuals use to express their thoughts, } \\
\text { feelings, questions, decisions, strategies, and plans } \\
\text { regarding the cultural experience }\end{array}$ \\
\end{tabular}


authentic representatives of the target culture as well as bilingual and bicultural. This assumption has implications for the countries and schools where the target language is not taught by native language speakers. In Kosovo's case EFL/ESL courses are overwhelmingly taught by local teachers who are not native English speakers and thus are not authentic representatives of either American or English cultures.

From the four stages that are represented in the Moran's Knowing framework (2001), this article only addresses the first two by examining the English curriculum, and a textbook, i.e. the article can only make claims whether curricular documents, and textbooks provide classroom opportunities for Knowing How and Knowing About of the target culture in EFL/ESL contexts in Kosovo. Further, for the specific needs of the study, the first two stages are collapsed into one, while the last two stages, namely Knowing Why and Knowing Oneself cannot be addresses here since the data material is limited to textual ones.

\section{Literature Review}

In the globalized world, teaching culture for intercultural understanding or cultural awareness is an important topic. This is the case, in particular, when considering the position that many educational systems around the world try to educate their students to be "global citizens" in the hyper-interconnected world (Peiser \& Jones, 2014). In other words, educational systems try to develop among their students an imagined identity that transcends their physical boundary. The imagined identity relates to individuals imagining being part of imagined communities, which refer to "groups of people, not immediately tangible or accessible, with whom we connect through the power of imagination" (Norton, 2013, p. 8). In many ways, language learners learning another language that belongs to an imagined community, i.e. another nation far from the immediate context of the learner, experiences that remote nation or the imagined self both through language and culture. In either case, irrespective of whether the goal for students is to become a 'global citizen', or to develop an imagined identity, or an alter-self, students have to be exposed to both target languages and cultures to be able to achieve the goals of global citizenship. Here, 'global citizen' is noted to mean '[...] one who 'responsibly' interacts with and 'understands' others while being self-critical of his/her position and who keeps open a dialogical and complex understanding rather than a closed and static notion of identities" (Pashby, 2011).

For small countries such as Kosovo, learning a second or a foreign language is an opportunity to start developing the knowledge, skills and understanding of the language they learn, which most often is English, and the cultures in which it is embedded. However, little is known about ESL teaching and learning in the Kosovo context. In a few recent cases, authors have examined the implementation of the latest ESL curriculum in upper secondary schools (Kasumi, 2016), or comparative analyses have been completed to explore differences in ESL teaching and learning between Kosovo and Portugal within the European context (Bekteshi, 2017). Still, considering the status of lingua franca that English has achieved worldwide, English for Kosovo students, as well as for the entire society, is an opportunity to assist 
students developing their imagined identities. Being a pro-Western and pro-American society, this push is not difficult for education policy-makers, as they know the students and their families place a high value on learning English. In other words, there is no resistance to learning English in Kosovo as it is viewed as a bridge or window to the developed world.

However, to be able to successfully operate as a global citizen or as part of the imagined community in case students ever actually immerse in those communities, they need to develop the cultural awareness and intercultural and cross-cultural understanding. "Developing cultural awareness means being aware of members of another cultural group: their behavior, their expectations, their perspectives and values. It also means attempting to understand their reasons for their actions and beliefs" (Cortazzi \& Lin, 1999, p. 216). It requires a special classroom environment for students to be able to develop cultural awareness. As Cortazzi and Lin (1999) highlight, having teachers who are reflective about the target culture as well as textbooks that include cultural elements of that culture are the preconditions for students to develop the aspired cultural awareness. In order for learners and teachers to develop intercultural awareness over time, it is important for them to begin understanding the target cultures (and all cultures, including their own) as complex, contested and changing.

Language and culture are inseparable and as such they should have equal weight in second language classrooms (Kramsch, 1991, 1993; Kramsch et al., 1996). Further, Kramsch (1991) considers that the core objective of the second language should be to teach it within the cultural context of the target culture, and not only focus on the traditional language skills, such as reading, listening, speaking and writing. Cultural awareness and the acquisition of a second culture can assist mastery of the language proficiency (Kramsch, 1993). From this perspective, teaching culture not only serves as an opportunity to gain cultural understanding of 'the other' or 'the imagined community' but also aids cognitive development and cognitive skills pertaining to the given second or foreign language.

Still, despite the push for integrating the goals for intercultural understanding into the second language curriculum, there is not much research to show that students are able to acquire a second culture similar to, and as a part of, the second language (Byram, 2008; Lantolf, 1999; Risager, 2012). There might be a number of plausible explanations as to why that is the case. One could be that English as Second Language (ESL) teachers, for example, lack the understanding of the target culture in the first place. The second plausible explanation might have to do with the curriculum in place for the second language, which simply cannot accommodate the target culture component due to emphasis on the language topics needing primary attention in an ESL classroom.

The teacher education programs are crucial for preparing language teachers to be able to integrate the target culture into classroom activities as cultural learning component is an unknown territory for language teachers (Byram, 1997, 2008; Byram \& Morgan, 1994). Language teachers are "[...] most often with an education in the literature of the language(s) they teach, and a training in the discipline of the literary criticism and the theory and practice of teaching linguistic knowledge and skills" (Byram \& Morgan, 1994, p. 1). Further, Byram and Morgan (1994) note that in their 
research they had found that students get some information, but very little knowledge of the foreign culture through the language classes. However, as they highlight, the cultural component is of paramount importance to make students aware of other cultures and understand others as well as themselves in the interconnected world. Thus, cultural awareness serves as a connecting point between the individual and the global society they are part of.

While the cultural component of the language has gained momentum and the idea of teaching language cognitively only is not as strong, there is a mismatch between the language policies that national or cross-national institutions promote and teaching practices of teachers on school contexts (Garrido \& Álvarez, 2006). Despite the relevance placed on it, teaching the cultural component remains a discrete choice and option of the individual teachers (Peiser \& Jones, 2014). Again, if teachers do not possess the understanding of the target culture, and are not willing to explore the potential of the target culture in their language classes, the cultural awareness will never really make it to the classroom. In that case, students are left to their own devices to explore the culture of the language they learn through other avenues, if they choose to do so. However, if teachers pay more attention to the cultural component, then, they provide opportunities for their students to get more educated insights into the target culture-otherwise students will be exposed to unfiltered conceptions they may get from the out-of-school world.

Lastly, the integration of the target culture into ESL learning has been criticized as an element that disrupts with students' own schema of their own language and culture (Alptekin, 1993). When learning a language, students rely on schematic knowledge, which is socially acquired, and systemic knowledge, which includes formal syntactic and semantic properties of language (Widdowson, 1990). As Alptekin (1993) notes, students learning English as a second language lack schematic knowledge because in most cases they do not have the direct social experience of the target language as used by native speakers, and only have to rely on knowledge of formal English language properties as taught in school. From this perspective, the tension arises between students' own schema of their native language and introduction of target culture into ESL learning. However, incorporation of target culture into ESL is the closest to making it possible for students to experience English as it is socially and culturally used by native English speakers.

\section{Data and Methodological Considerations}

The data for this study comprises of policy documents published by the Kosovo education authorities, primarily the Ministry of Education, Science and Technology (MEST). Table 2 lists the key documents and the textbook included in the document analysis, where the focus was on examining the extent to which the key policy documents addressed the issue of teaching culture through teaching English as the first foreign language as is the case in Kosovo's K-12 curriculum. The study used document analysis as a qualitative research method to meet its aims. "Document analysis is a systematic procedure for reviewing or evaluating documents-both printed and electronic (computer-based and Internet-transmitted) material" (Bowen, 2009, p. 


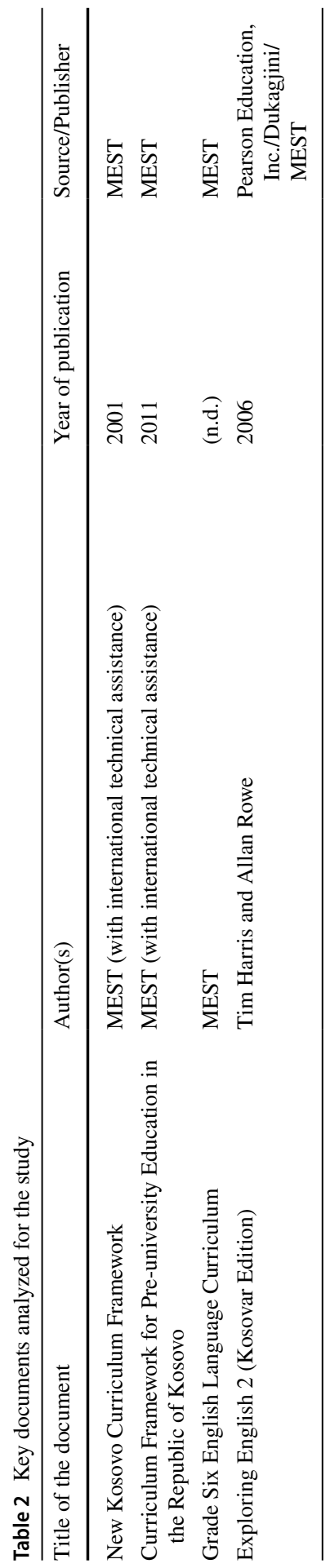


27). In the analysis of key curriculum documents, the focus was on identifying provisions that were relevant for teaching and learning of English language in Kosovo's curricula more broadly and grade six curriculum specifically.

Teachers in Kosovo rely on a textbook to teach English in any given grade in K-12 schools. The textbooks that teachers use in lower secondary schools are a series called Exploring English (1-4) by Tim Harris and Allan Rowe (2006). They are adapted for the Kosovo context by a group of local consultants, and published by the Kosovo's Ministry of Education, Science and Technology. For the data collected from the Exploring English 2 textbook (used at Grade 6), as the main data source, Moran's (2001) Knowing framework was used as the guiding data collection protocol relying on the first two dimensions of the framework, referred to as Knowing about and Knowing how. The textbook was also analyzed to find cultural dimensions as presented by Moran (2001), primarily products and practices, and to a less extent perspectives, communities and persons. All analyses were completed by the author, and the results from the English textbook were validated by consistently reviewing them against Moran's (2001) Knowing framework that served as a guide for both data collection and data analysis. The analyses of the data material followed deductive reasoning to discern patterns and categories related to the guiding theoretical framework, while coding of entries was based on summative content analysis (Hsieh \& Shannon, 2005).

\section{Results and Discussion}

Curriculum frameworks have served as guiding policy documents for subject curriculum development in Kosovo. Frameworks outline the goals and principles of the $\mathrm{K}-12$ education system. Therefore, findings from the analysis of the two frameworks (MEST, ) are provided first. The 2001 framework explicitly emphasizes the target culture and the cultural awareness as key elements of the English language as a first foreign language to be included in the pre-university education. It notes that "The acquiring of English language will allow students to get in close contact with the culture and traditions of other nations, to access and share information at an international level and to be part of the today's interdependencies actively" (MEST, 2001, p. 57). Further, it highlights that "The cultural awareness dimension, which is linked with the studying of English language, will also provide a sound basis for the development of a wider sense of identity and of effective tools for mutual understanding" (MEST, 2001, p. 57).

The 2001 framework recognizes the role the target culture should play in studying English in Kosovo context and acknowledges the role of the language in fostering cultural awareness of other cultures and traditions. However, the framework is not specific about what constitutes the target culture, and there is no specific mentioning of either American or English culture. Furthermore, it emphasizes that English should serve as a window to "other cultures and traditions". From this perspective, English language has to meet a set of objectives: first, teach students the key linguistic competences, introduce students to the target culture as well as other cultures and 
traditions, and ultimately prepare students to operate at the international level for today's interdependent world.

The 2011 curriculum framework did not have anything specific related to English language or other foreign languages or the target culture or cultures in which they are embedded. The only references to culture were made as part of the broad aims of education, which among else, include, the development of students' personal and national identity, statehood and cultural belonging. The 2011 framework aims to encourage students to cultivate their curiosity and positive attitudes towards difference, in terms of ideas, phenomena, persons and cultures. This is in no way related to English only, however, it highlights the goal for preparing students for being able to live with others and become tolerant to others' views and perspectives, including those of other cultures, both locally and internationally.

The Grade Six curriculum for English language was developed immediately after 2001 framework and thus it was developed based on it, while subject curricula are still being revised to reflect the goals and objectives of 2011 curriculum framework. One feature of the Grade Six curriculum is that it is full of references to culture, and shares the aims and objectives for intercultural awareness of 2001 framework. Specifically, the Grade Six curriculum recognizes that "The development of cultural understanding and linguistic proficiency is a complex process involving a variety of language experiences and exposure to the culture of other people whose language is being studied" (MEST, n.d., p. 32). It also notes that that "[Students] will deepen their understanding of their own culture and other cultures, where English is spoken as a first, second or an international language" (MEST, n.d., p. 32).

One component that is extended in the Grade Six curriculum pertains to the notion that the English language goal should be not only to make students aware of other cultures, but also deepen understanding of their own culture. This was a surprise finding as usually the literature on teaching English and its accompanying culture does not include this additional objective of also teaching students of their own culture. In general, this is a task for students' own language course, such as Albanian, or Serbian, in Kosovo's case, as well as in other courses such as civic education, history, geography and the arts. Further, the Grade Six curriculum specifies the key topics that students will study over the year and these are directly taken from the contents of the Grade Six textbook for English Language titled Exploring English 2 (Kosovar Edition) (EE2).

The main focus of the EE2 textbook, as highlighted in its Preface, is teaching the four language skills - listening, speaking, reading, and writing-with an emphasis on oral communication (Harris \& Rowe, 2006). In addition, it also notes that it combines a strong grammar base with an in-depth coverage of language functions and life skills. Regarding the Kosovar Edition of Exploring English, it is noted that it:

$[\mathrm{P}]$ resents characters and situations in a Kosovar setting with many of the primary characters assuming the identities of members of the local communities. In addition, several characters retain their original identities as Americans or other internationals who are living and working in Kosova. That makes it possible for the local characters to explore the interests and cultures of their foreign guests and the members of the international community are also offered 
numerous opportunities to discover more about the local culture (Harris \&

Rowe, 2006, p. x)

Nevertheless, findings suggest that the EE2 textbook does not live up to the aspirations highlighted here. One of the broad conclusions is that the book promises to do too much and delivers too little - especially with regard to the introduction of students to the target culture(s). For example, the textbook does not have any reference to the British culture, as one of the few key cultures in which English is embedded.

In the following section, the main findings from chapters 1 and 2, out of the total 8 chapters in EE2 textbook, are presented in Table 3, and then both chapters 1 and 2 as well as the remaining 6 are elaborated on, as each EE2 textbook chapter follows the same format with same characters representing local and international communities. The examples represented here only pertain to the two stages of Moran's Knowing framework, namely Knowing About and Knowing How. For the purposes of discussion here, these two stages are collapsed into one, as it is impossible to differentiate between the two only based on the text entries

Table 3 Examples of cultural dimensions in Chapters 1 \& 2 from Exploring English 2 textbook

\begin{tabular}{|c|c|}
\hline $\begin{array}{l}\text { Five cultural } \\
\text { dimensions } \\
\text { (Moran, 2001) }\end{array}$ & Examples found in Exploring English 2 Textbook \\
\hline \multicolumn{2}{|l|}{ Chapter 1} \\
\hline Products & Turkish coffee, yogurt, byrek \\
\hline Practices & $\begin{array}{l}\text { 1. Sam always has byrek and yogurt for breakfast } \\
\text { 2. Mr Belegu: Turkish coffee is my favorite drink } \\
\text { 3. Otis is a vegetarian } \\
\text { 4. Gloria usually has tea, toast, and cheese for breakfast }\end{array}$ \\
\hline Perspectives & Food... \\
\hline Communities & $\begin{array}{l}\text { Prishtina, Prizren, City Bank, Grand Hotel, Drini's Caffe, Fisniku's garage, } \\
\text { Martinoli Restaurant }\end{array}$ \\
\hline Persons & $\begin{array}{l}\text { Jeta Hoxha, Sam Brown, Ana, Mr \& Mrs. Begu, Mr \& Mrs. Limani, Mr \& } \\
\text { Mrs. Belegu, Jimmy, Linda, Otis, Jeton, Artan, Mentor Hadri, Gloria Cole, } \\
\text { Kate, Harry, Marko, Petar, Nada }\end{array}$ \\
\hline \multicolumn{2}{|l|}{ Chapter 2} \\
\hline Products & International Menu, Prices in Euro, baklava \\
\hline Practices & $\begin{array}{l}\text { 1. Fisnik's garage has free coffee for customers, doughnuts too } \\
\text { 2. Marko (who drives a local taxi with KS plates) often meets foreign visitors, and } \\
\text { he gives them useful information about Prishtina } \\
\text { 3. Faruk (Albanian) and Marko (Serbian) are good friends }\end{array}$ \\
\hline Perspectives & Food... \\
\hline Communities & Fisnik's Garage, School Library in Prishtina, Drini's Café \\
\hline Persons & Suzi Suzuki, Jimmy Brown, Tino Martinoli, Faruk \\
\hline
\end{tabular}

The bold items in the table above refer to local Kosovo cultures, which in this textbook include Albanian, Serbian, and Turkish to represent the multicultural nature of the country. The items in italics refer to the English culture, which in this textbook primarily pertains to the American culture. The underlined items refer to other international cultures, in this textbook Italian, Spanish, French and Asian. Byrek is a local/ regional pastry and baklava a local/regional sweet in the Balkans. 
in the textbook. Table 3 is a representation of the cultural examples identified in the first two chapters of the EE2 textbook, while other examples are not shown to avoid redundancy and repetition.

As Table 3 shows, examples for all cultural dimensions from Moran's (2001) framework were identified, and as noted under the theoretical framework, these examples concern the first two dimensions of the Knowing framework, namely: Knowing about and Knowing how. The examples shared in Table 3, as well as other cultural elements identified throughout the textbook show interesting findings. First, in line with the Kosovo curriculum framework (2001) it is clear that students are exposed to a diverse group of international nations (references to American, Italian, French, Asian people, places and food mostly), thus giving them the opportunity to get in touch with cultural products, practices and communities beyond their immediate context.

Second, and most interestingly, the contextualization of most of the events and dialogues in the textbook within Kosovo seems to produce two contradictory outcomes: on one hand, it presents Kosovo as an international place where many internationals live, share, and experience the Kosovo culture (e.g. Sam Brown eating byrek), while on the other hand, it also presents a distorted view of what Kosovo is and where it is located (e.g. characters in the events go swimming in the oceanwhile Kosovo is a landlocked country). Further, this second point limits the opportunities for students to know about other places and cultures if the events in the textbook were placed in international countries. In other words, the textbook lacks authenticity.

Third, the local characters in the textbook represent both Albanian (e.g. Jeta, Artan, Mentor) and Serb (e.g. Petar, Nada, Marko) communities. They are shown in the textbook to be good friends with one another and often engage in joint activities. The representation of these two communities is an effort to show Kosovo as a multicultural country, while there is no ethnic or religious reference of the two communities presented in the textbook. Further, the events in EE2 with regard to joint activities of Albanians and Serbs represent a policy effort to bring these two communities together through education. However, in reality Albanians and Serbs within the Kosovo context still live overwhelmingly separate from one another, often under hostile and tense circumstances. The education divide between the two communities is most striking - where Serbs use curriculum and textbooks developed in Serbia, and only Albanians and non-Serb minorities in Kosovo are exposed to the ESL textbook discussed here.

Fourth, the representation of the target culture is skewed towards the American culture, with only one reference to London, the UK, in the whole textbook. Also, there is a representation of other places and cultures other than English ones, so there is no clear sense of one specific target culture. What the textbook tries to do is well in line with the objectives defined for the English language in the 2001 Kosovo curriculum framework and in the Grade Six curriculum for English language, where English is viewed as an international language, rather than a language of a specific number of countries. In that vein, English is promoted as a unifying language of nations, where American, local and other international characters in the events in the textbook communicate with one another in English. 
Similar to examples from EE2 Chapters 1 and 2 above, the other six chapters follow the same thread where the same characters interact and create friendships and relationships with one another. Food is mentioned in almost all the chapters. For example in Chapter 3: "Mrs. Brown is a good cook. She can make spaghetti, fried chicken, byrek and baklava" and "Mr. Brown can eat a whole chicken, a chocolate cake, three hamburgers and mantias". These two examples again show the mix of American, international and local food that American characters in the textbook can cook or eat. Further, the examples indicate that Americans are open and have adapted to local Kosovo culture by cooking and eating local foods, thus suggesting to the students that they could do the same if they ever live in another international context. Then, there is a reference to an Italian restaurant in Prishtina, owned by the Martinoli family. They serve Italian food, music and talk about Venice. Further, there is a brief mention of American culture, when Linda wants to go to the Star Cinema (inexistent in Kosovo) to watch a western movie called The Last Texan.

If the stories happen in the open environment in Kosovo, the locations include Mother Teresa Street, Ulpiana or Pishat Street - all references in Prishtina, the Kosovo capital. Regarding weather, chapter 5 shows examples of use of both Celsius and Fahrenheit degree, and the major cities in Europe and New York are mentioned. Locally, only Celsius degree is used.

Other cultural references are made as characters of the textbook travel around the world. For example, they travel to Europe-mainly Italy, Spain and Franceand Sam Brown travels to New York City where he visits some cultural places such as: Statue of Liberty, Empire State Building, United Nations and watches a play on Broadway. There is no elaboration or any other additional point made about these places. Further, there is a small conversation between an American from New York and a Kosovar from a small town called Lipjan. He says New York is crowded and noisy and the Kosovar replies Lipjan is peaceful. Lipjan is the only reference made to a place or location outside Prishtina in Kosovo.

Overall, the textbook relies heavily on the four language skills and grammar component. Further, the international characters participate in events in the textbook but they do not share much of their respective cultural background. In a sense, international characters are presented to the students just as one of them - they are shown living in Kosovo, cooking and eating local food, working in Kosovo institutions, and going out and have fun, similar to local characters. While this is to some extent in line with the goals shared in the English language curriculum for students to become global citizens, representing the whole world living and working in the Kosovo context together mutually understanding one another linguistically and culturally, it deprives Kosovo students of experiencing more of the target culture. Research has shown that students learning a foreign language are interested in the target culture (Lenchuk \& Ahmed, 2014). Further, the textbook does not introduce students to variations of English language as spoken in several corners of the world, which might be an intentional decision of those who developed and edited the book, but it might lead to misconceptions of students about variations of English language internationally. 


\section{Conclusion and Recommendations}

This study explored the opportunities for teaching and learning cultural awareness through English language using the Grade Six curriculum and textbook in Kosovo context. It sought to identify what opportunities Kosovo students in Grade Six have to develop their intercultural awareness through studying English language. The findings, in line with the literature, show that developing students' cultural awareness is an important component as highlighted in the Kosovo policy documents. The vision shared in the documents and curriculum faces challenges when it comes to translating it into specific teaching and learning opportunities for students in the classroom contexts. The analysis of the Grade Six textbook, i.e. Exploring English 2, showed that the cultural references made in the textbook are not particularly embedded in any specific target culture or cultures. On the contrary, it shows the English language as an international language spoken by everyone everywhere, without an authentic cultural component attached to it. In particular, it was revealing to identify how almost all events in the textbook are situated in Kosovo and characters of the events, including primarily local, as well as American and other international characters, engage in joint activities and consuming mixed cultural products - mostly related to food, which is one of the most recurring topic in the textbook. Further, the local characters included in the textbook include both Albanians and Serbs to show the structural multicultural context, and they are involved in joint activities as good friends, while in reality, these two communities overwhelmingly continue to be divided along ethnic lines.

Given the situation identified with English language in the Grade Six in Kosovo, with regard to teaching culture for the purpose of developing students' cultural awareness, three main recommendations are offered. First, teaching culture needs to be better represented and integrated in the teacher education programs that train English language teachers in Kosovo. Those programs of study need to better reflect the aspirations shared for English language in the Kosovo curriculum framework, and the English language curricula. Moran's (2001) framework could be used in these programs to help language teachers explore cultures and compare and contrast with their own so they help their students be reflective about their own culture. Second, the series of textbooks in use for English language need to maintain their emphasis on preparing students for participating and contributing to the interdependent and interconnected world as global citizens, but students would benefit far more if more authentic cultural elements are integrated, especially with specific emphasis on the American and the British cultures. Third, and this applies not only to Kosovo teachers but potentially to English teachers internationally as well, ESL/EFL teachers need to be more creative in utilizing the textbooks in use as well as other resources available online and offline to introduce students to the target culture(s)' experiences that help students better understand themselves as well as cultures of those who speak the language they spend a lot of time trying to master. While it is obvious that there is a shortage of materials to teach culture, some of the ways that teachers can employ include critical incidents, experiential activities, cultural simulations, 
field experiences, role-plays, films, literature, realia, and other authentic materials (Moran, 2001). A deeper exploration of the diversity within the target cultures might give Kosovo learners the understanding and skills needed to relate to the diversity within Kosovo. This step could have a better chance to be accomplished if all Kosovo students learnt from the same Kosovo textbooks. The fact that Serb community students learn from textbooks produced in Serbia limits the opportunities for more integrative approaches to teaching and learning for one another in the way that Kosovo curricula and textbooks are intended for. It follows from here that ELS teaching and learning in Kosovo, and integration of intercultural awareness into ESL, could benefit from two major developments: first, better alignment of ESL textbooks as well as ESL teacher education programs with national curriculum aspirations, and second, integrating Serb community into the national education system so that all Kosovo students have a better opportunity to learn both about the foreign cultures as well as cultures shared among diverse Kosovo local communities.

The study identified misalignment and mismatch between the ESL curriculum and the textbook in use. The lack of coherence across different teaching and learning materials and resources affect students' capacities to develop the cultural awareness much needed and aspired for in the twenty-first century. Students need to develop, what is referred to here as, "a culturally-colored outlook" in order to be able to cope with environments and contexts, near and far, that surround and affect them in multiple ways. The culturally-colored outlook would require students to view people and nations not only through their own cultural lenses but through multi-cultural lenses that assist them to consider themselves as well as others part of the same increasingly interconnected and highly interdependent world.

Funding Open access funding provided by NTNU Norwegian University of Science and Technology (incl St. Olavs Hospital - Trondheim University Hospital). This study didn't receive any funding.

\section{Declarations}

Conflict of Interest The author declares she has no conflict of interest.

Ethical Approval This article does not contain any studies with human participants or animals performed by the author.

Open Access This article is licensed under a Creative Commons Attribution 4.0 International License, which permits use, sharing, adaptation, distribution and reproduction in any medium or format, as long as you give appropriate credit to the original author(s) and the source, provide a link to the Creative Commons licence, and indicate if changes were made. The images or other third party material in this article are included in the article's Creative Commons licence, unless indicated otherwise in a credit line to the material. If material is not included in the article's Creative Commons licence and your intended use is not permitted by statutory regulation or exceeds the permitted use, you will need to obtain permission directly from the copyright holder. To view a copy of this licence, visit http://creativecommons.org/ licenses/by/4.0/. 


\section{References}

Alptekin, C. (1993). Target-language culture in EFL materials. ELT Journal, 47(2), 136-143. https:// doi.org/10.1093/elt/47.2.136

Agjencia e Statistikave të Kosovës [Kosovo Statistical Agency] (ASK). (n.d.). Kosova me pak fjalë [Kosovo in brief]. Retrieved from http://ask.rks-gov.net/.

Bekteshi, E. (2017). English language teaching and the common European frame of reference A comparison of ELT in Portugal and in the Republic of Kosovo. ANGLISTICUM. Journal of the Association-Institute for English Language and American Studies, 6(1), 40-53. https://doi.org/ 10.0001/(aj).v6i1.1408

Bowen, G. A. (2009). Document analysis as a qualitative research method. Qualitative Research Journal, 9(2), 27-40. https://doi.org/10.3316/QRJ0902027

Byram, M. (2008). From foreign language education to education for intercultural citizenship: Essays and reflections (Vol. 17). Multilingual Matters.

Byram, M., \& Morgan, C. (1994). Teaching-and-learning language-and-culture. Multilingual Matters.

Byram, M. (1997). Teaching and assessing intercultural communicative competence. Multilingual Matters.

Chen, G. M., \& Starosta, W. (1998). A review of the concept of intercultural awareness. Human Communication, 2, 27-54.

Cortazzi, M., \& Jin, L. (1999). Cultural mirrors: Materials and methods in the EFL classroom. In E. Hinkel (Ed.), Culture in second language teaching and learning. Cambridge University Press.

Garrido, C., \& Álvarez, I. (2006). Language teacher education for intercultural understanding. European Journal of Teacher Education, 29(2), 163-179. https://doi.org/10.1080/026197606006173 42

Harris, T., \& Rowe, A. (2006). Exploring English (Kosovar). Dukagjini.

Hinkel, E. (1999). Culture in second language teaching and learning. Cambridge University Press.

Hsieh, H. F., \& Shannon, S. E. (2005). Three approaches to qualitative content analysis. Qualitative Health Research, 15(9), 1277-1288.

Irie, K. (2003). What do we know about the language learning motivation of university students in Japan? Some patterns in survey studies. JALT Journal, 25(1), 86-100.

Kasumi, H. (2016). The implementation of Kosovo Curricula regarding the English Language Teaching. International Conference Proceedings on Linguistics, Literature and Culture.

Kramsch, C. (1991). Culture in language learning: A view from the United States. Foreign Language Research in Cross-Cultural Perspective. https://doi.org/10.1075/sibil.2.21kra

Kramsch, C. (1993). Context and culture in language teaching. ERIC. Retrieved from http://eric.ed. gov/?id=ED371633.

Kramsch, C., Cain, A., \& Murphy-Lejeune, E. (1996). Why should language teachers teach culture? Language, Culture and Curriculum, 9(1), 99-107. https://doi.org/10.1080/07908319609525221

Lantolf, P. J. (1999). Second culture acquisition: Cognitive consideration. In E. Hinkel (Ed.), Culture in second language teaching and learning. Cambridge University Press.

Lenchuk, I., \& Ahmed, A. (2014). Teaching pragmatic competence: A journey from teaching cultural facts to teaching cultural awareness. TESL Canada Journal, 30(7), 82. https://doi.org/10.18806/ tesl.v30i7.1153

Lipovec, N. Č. (2017). Tracing intercultural and interlinguistic moves within and beyond student mobility programmes: The case of the IEREST project. Studies in Second Language Learning and Teaching, 7(2), 211-232.

Ministry of Education, Science and Technology, MEST. (2011). Curriculum framework for preuniversity education in the Republic of Kosovo. Ministry of Education Science and Technology MEST.

Ministry of Education, Science and Technology, MEST (n.d.) Grade Six English Language Curriculum. Retrieved from http://www.masht-gov.net/advCms/documents/klasa_6_ENGLISH_ LANGUAGE.pdf.

Ministry of Education, Science and Technology. (2001). New Kosovo Curriculum Framework. First Draft, Kosovo.

Moran, P. (2001). Teaching culture: Perspectives in practice. Heinle \& Heinle.

Norton, B. (2013). Identity and language learning: Extending the conversation. Multilingual Matters. 
Pashby, K. (2011). Cultivating global citizens: Planting new seeds or pruning the perennials? Looking for the citizen-subject in global citizenship education theory. Globalisation, Societies and Education, 9(3-4), 427-442. https://doi.org/10.1080/14767724.2011.605326

Peiser, G., \& Jones, M. (2014). The influence of teachers' interests, personalities and life experiences in intercultural languages teaching. Teachers and Teaching, 20(3), 375-390. https://doi.org/10. 1080/13540602.2013.848525

Phillipson, R. H. L. (1992). Linguistic imperialism. Oxford University Press.

Risager, K. (2012). Linguaculture and transnationality: The cultural dimensions of language. The Routledge handbook of language and intercultural communication (pp. 117-131). Routledge.

Tahirsylaj, A. (2018). Curriculum reform as a political statement in developing contexts: A discursive and non-affirmative approach. Transnational Curriculum Inquiry, 15(2), 38-49.

Tahirsylaj, A. (2013). Educational change in post-war Kosovo: Perceptions of Kosovo educators as presented in Shkëndija. Interchange, 44(1-2), 1-13.

Vettorel, P., \& Lopriore, L. (2013). Is there ELF in ELT coursebooks? Studies in Second Language Learning and Teaching, 3(4), 483-504.

Widdowson, H. G. (1990). Aspects of Language Teaching. Oxford University Press.

Publisher's Note Springer Nature remains neutral with regard to jurisdictional claims in published maps and institutional affiliations. 